Jean Morrison's definitive Labour Pains: Thunder Bay's Working Class in Canada's Wheat Boom Era ${ }^{1}$ by extending the research past 1914 into the inter-war period.

\title{
NOTES
}

1 Jean Morrison, Labour Pains: Thunder Bay's Working Class in Canada's Wheat Boom Era (Thunder Bay: Thunder Bay Historical Museum Society Inc., 2009).

Saku Pinta

Independent Scholar

\section{Samuel Kalman and Sean Kennedy, eds., The French Right between the Wars: Political and Intellectual Movements from Conservatism to Fascism. (New York: Berghahn Books, 2014). 274 pp. $\$ 95.00$ Hardcover.}

Studies of the French right are far from rare in the corpus of North American and British scholarship of Modern France. Indeed, the fascination with fascism, or, to be more precise, the question of whether fascism existed in France in the twentieth century, has occupied the minds of many historians. The debate about the so-called "immunity thesis", which suggests that France was immune to the appeal of fascism in the 1930s, has in many ways pitted French historians, working from a model first elaborated by the eminent historian René Rémond, against their Anglo-American counterparts, who were often keen to remind their colleagues that the right in France was far larger, more influential, and more inclined towards fascistic tendencies than Rémond had been willing to acknowledge. The fact that this debate has animated some excellent work, both in France and beyond, should not be taken as a rationale to continue having it as the central question for scholarly inquiries into the political life of the late Third Republic. The question of fascism's popularity in France and the attempt to categorize political groupings, labeling them with clear ideological boundaries, has served to mask just as much as it has uncovered.

For this reason, among others, Samuel Kalman and Sean Kennedy's edited collection, The French Right between the Wars: Political and Intellectual Movements from Conservatism to Fascism, is a welcome addition to the field. Although some contributors still use more traditional categories of analysis to assess the French right of the interwar years, others seek to redefine the parameters of analysis entirely. While some essays seek to comment on whether the rightists under question were disposed towards fascism or helped weaken the Third Republic, others attempt to highlight the similarities between the culture of the right and the left, or go even further to question whether labels of right and left, in the context of our contemporary understandings, are appropriate for 
continued use. The goal of moving beyond categorization and into a deeper historicization of these topics should be applauded and it is thanks to these goals that the collection has two key strengths that set it ahead of the pack.

The choice of topics included in the collection reflects the fact that it is impossible to talk of the French right as a singular, unchanging entity. The very complexity of the various groupings within the right, broadly speaking, demand a flexible approach to their study - an approach that is used by most contributors. The movements and political parties of the right often displayed a fluidity of ideology and practice that allowed them to shift loyalties, strategies, and emphasis. Moreover, as Kevin Passmore (also a contributor in this volume) has recently highlighted in his new book, 1 the people who joined these leagues and parties also had multi-faceted identities. Being a member of a rightist league did not always translate into expected courses of action, because loyalties could be divided. The authors of the all the essays in this volume take seriously the need to think about how people in the 1930s perceived their political reality, as opposed to our tendency to impose upon them our own ideas of social and political structures and how they are formed and dismantled.

A second strength of the collection is the fact that the wide range of subjects allows for a wide range of perspectives from the contributors. From veterans' movements, to traditional Catholic organisations, to mass parties capitalizing on the populist élan of the 1930s, to strands of pacifism, a multitude of rightist tendencies are analyzed in the book. This diversity, as we might imagine, means that the historians who contributed to the collection do not always have the same point of view - a refreshing change from edited collections that gloss over important scholarly debates and points of contention. Here, readers are treated to divergent opinions, which allow them to draw their own conclusions or, if so inclined, take these essays as starting points for further research. A perfect example of this is found in the very interesting section on gender and the French right, made up of four essays. The gender dynamics of the French right, and particularly the French far-right, have been fruitfully explored in recent years by several talented historians, many of whom have contributed to this volume. Their conclusions about the ways in which norms of masculinity and femininity intersected, changed, and were changed by the right differ and ultimately suggest that there is plenty of room for further discussion about gender and politics in 1930s France.

As with many edited collections, the strength of each contribution varies somewhat, but given the four main thematic strands - methodology and new scholarly orientations, gender, intellectual and cultural trends on the right, and historiography - readers with diverse interests will likely find the overall collection useful and stimulating. The collection should also help to move research beyond the fascination with fascism into a deeper understanding of French politics, both left and right, in the interwar period. 


\section{NOTES}

${ }^{1}$ Kevin Passmore, The Right in France from the Third Republic to Vichy. (Oxford University Press, 2012).

Valerie Deacon

New York University 